\title{
Learning Styles of Students as a Factor Affecting Pedagogical Activities of a University Teacher
}

\author{
https://doi.org/10.3991/ijet.v12i02.6277 \\ Martin Malcik \\ VSB - Technical University of Ostrava, Czech Republic \\ martin.malcik@gmail.com \\ Miroslava Miklosikova \\ VSB - Technical University of Ostrava, Czech Republic. \\ miroslava.miklosikova@vsb.cz
}

\begin{abstract}
Social changes demand a continuously increasing level of population erudition, which is to be helped by an increased quality of university education. University graduation poses a demanding study activity for students, which requires self-regulation mechanisms, attention and effective curriculum processing. University teacher can help effective learning by respecting the learning styles of students, which are closely connected to their type of thinking. Some experts [1] assume that study texts should be created in a way to reflect the type of thinking of students; i.e. serial thinking students require a differently structured study text as opposed to holistic thinking students.

In this research, using the eye-tracking technology, we examined whether technically oriented students use serial thinking for acquiring and processing information and for the following problem-solving and whether humane education students use holistic thinking.
\end{abstract}

Keywords-Holistic thinking, learning styles, learning strategies, serialistic thinking.

\section{Introduction}

The effort to increase the efficiency of the education process is more prominent during periods of faster social developments. The characteristic trait of the current development is focus on human's individuality, thus researchers focus on individual methods that people use to process new information, learn and solve problems. This trend is also connected with the pressure on people's performances, to which university teachers and students of technical study programs are no exception.

Methods used by students to orientate in text and process new information (curriculum) that they use to solve exercises afterwards is based on the character of their thinking, intelligence, meta-cognitive abilities and personality characteristics. These individual differences among students should be respected by the teacher and carefully affected to an extent. It has been a long time ago since students had sole responsi- 
bility for their results; university teachers are increasingly more pressed to accept their share of responsibility. The knowledge of psychological processes connected with learning, learning strategies and styles, and meta-cognitive abilities is therefore becoming a necessary part of the academic profession [2].

Individual learning methods are characterized differently by experts. Mareš [3], [4] sees them as learning tactics, strategies or styles, approaches to learning, ways of thinking, etc. These terms not only clarify the learning process, but also explain why a specific student learns in a certain way and achieve certain results. The author defines learning style as a sum of procedures, which are used by an individual during learning, in a specific time period during most pedagogical situations. He further claims that these procedures are partially dependent on the content of learning, stem from innate foundations and are developed by a concurrence of internal and external influences. Student willingly chooses their learning tactics - they include practically organized procedures that together create a learning strategy. Learning strategy is characterized as a sequence of coherently ordered activities with the aim to reach a learning goal. The strategy helps students decide which abilities and in which order they use. Learning strategies are fixated and later automated and are closely connected with a learning style. There is the following relation between the learning style and learning strategies: learning styles is a learning meta-strategy and stands above individual learning strategies [4]. Student's success rate while solving an exercise is, therefore, dependent both on their learning strategy (plan) and their learning style, while strategies are easier to influence.

Learning method is also closely connected with the character of reasoning. Theorists mention e.g. abstract thinking, specific thinking or their combinations, etc. and emphasize its connection to other psychological cognitive and non-cognitive functions. According to Pisoň [5], using a systematic approach in education represents a type of thinking in which phenomena are understood as an organized set of elements with certain relations existing between them. Together they create a specific unit (structure).

Nakonečný [6] distinguishes deep or surface thinking, flexible or rigid thinking, quick or slow, independent or dependent, convergent or divergent, original or conventional among others, which shows the interconnection of thinking with personality traits. Pask [1] argues that the way a student thinks, is to a certain extent affected by the type of their study program. The "technically thinking" student may be inclined to think more serialistically, manifesting in their preference of rationality, sense of logic and rules, tendency to work with one hypothesis at a time and to work "step-by-step" when solving a difficult task.

\subsection{Technical and Humanistic Thinking}

Technical thinking according to Kropáč, Havelka [7] is a specific form of thinking which is delimited by the subject it pursues and its particularities. A significant character of technical thinking, for example, is the permanent relation of theoretical and practical elements, or by choice of devices to be used to reach a specific goal. Technical thinking has a complex form - when selecting the solution for a specific tech- 
nical problem, any technical and non-technical context must be taken into account. It is also clear that a specific technical task can be solved by various devices or technical possibilities, and it is dependent on the level of critical and evaluative thinking of the solver. Technical thinking incorporates mental operations such as analysis, synthesis, abstraction, concretization, classification, analogy and the ability to view an object or process in its entirety, therefore the necessity of systematic thinking is undisputable. Franus [8] believes that technical thinking comprises of two intertwining types of processes, specifically cognitive processes, which are predominantly analytic, and creative processes, governed mostly by synthesis.

Humanistic thinking is closer to students and graduates of liberal arts and social sciences that focus on people and societies. It is difficult to separate these sciences with a clear-cut dividing line, but social sciences tend to use quantification and traditional scientific methods, e.g. the experiment, while liberal arts tend to have a more analytic character.

\subsection{Understanding Text}

Understanding text is a psycholinguistic activity during which the following elements get connected:

- objective reality phenomena and text elements;

- individual elements of the text (words, sentences, higher-level units);

- elements of the text and the knowledge structure of the recipient.

Understanding has a relational character. It can only happen if the recipient identifies elements of the text, objective reality, and their own knowledge structure and puts them into mutual relations. It is a complex activity which requires analysis and synthesis of various layers of the text. Although the activity is enormously complex, it happens fast, and usually already during reading [9].

\subsection{Serialist and Holist Learning}

Pask [1] defined two learning styles - serialist and holist - and a series of methods on how to differentiate students based on the two styles. Pask divided study aids based on whether serialist or holist students should use them, and then compared the quality of their study performance with performance of other students who were assigned the text regardless their style of thinking. He found out that the best performance of incorrectly assigned students (students with holist thinking assigned study aid requiring serialist thinking and vice versa) was worse than the performance of students who were assigned the corresponding study aids. Based on his findings, Pask stated that textbooks, which were mainly serialist, should be updated with content, simplifying images, glossaries, etc. so that students would be able to find their own approach to learning. Holist projects focusing on the result and causing problems to serialist students should be updated with help information. 
Denicola [10] believes that if students had study aids in agreement with their preferred learning styles, they would learn more quickly and effectively. If they are provided with study aids that are not in sync with their learning styles, they learn slowly and ineffectively. While holist students will not enjoy impersonal lectures, serialists will dislike tedious simulations. Experiences from unpleasant learning may be strong to the extent that they complicate or even prevent further learning. The whole situation is further complicated by the fact that it is not only students with preferred learning styles, but teachers having their preferred teaching styles.

The abovementioned findings have led experts to believe that teachers should adapt their teaching style to students because permanent discord between the learning style of the student and the teaching activities can affect the education process by favoring some students and discriminating others. Moreover, it was proved that having a constant teaching style can lead to boredom, both on the sides of the teacher and students [11]. Students with a strong inclination to a single learning style often study ineffectively, while other students without a single go-to learning strategy accept "incompatible" teaching style as a challenge, which leads them to develop new learning strategies [12], [13]. It can be therefore noted that excessive adaptation of the teaching process to a single student or a small group of students limits the learning activities of other students.

The aim of this research is to find out which learning strategies - learning styles are chosen by university students of liberal arts and technical students when solving tasks and working with text; to find out whether there will be differences and which differences when these two groups of students solve tasks some of which require a holist and others a serialist thinking.

\section{$2 \quad$ Research Goal}

The goal of this research was to find out which learning style is preferred by university students when solving various types of tasks; whether there is a relation between their self-conception (when they perceive themselves as technical or humanist personalities) and their serialist or holist approach to texts; and whether there is a relation between their study focus and dominant learning style.

\subsection{Research Tools}

Questionnaire on Interest in Natural Sciences or Liberal Arts (DZPHV): Respondents (students) were introduced to a questionnaire which sought to find out whether they consider themselves as technically or humanistically oriented; it had statements to which students should show agreement or disagreement on the scale of $1-5$, where 5 is a complete agreement. The statements either had technically or artistically oriented activities and respondents were to indicate the extent to which these activities are close to them, how much interesting or boring they find them, etc. 


\subsection{Eye Tracking Technology}

For the analysis of how students process text and graphic material we often used Eye Tracking technology [14]. Eye tracker Tobii 300 was used to measure the number of eye movements and the length of eye fixations when respondents worked with the text and solved tasks and Tobii Studio (version 3.2.1) was used for the analysis.

\subsection{Respondents}

Respondents were non-paid university students aged 20-22 from the Faculty of Electrical Engineering and Computer Science of VŠB - Technical University of Ostrava, studying Computer Science program; and students from the Pedagogical Faculty of University of Ostrava, studying Pedagogy. Also included were non-paid students of the J. A. Komensky college, studying Media Communication. All students had normal or corrected-to-normal vision. None of the participants had experience with similar experiments. Out of the total of 16 respondents, there were 7 men and 9 women. The research took place between $20^{\text {th }}$ May 2015 and $20^{\text {th }}$ October 2015. Participants were told that they were to participate in an experiment on the speed and accuracy with which information could be extracted from different sources.

Respondents were given six different tasks to solve, and they had to use three different sources of information:

- one uninterrupted psychological text;

- one technical, statistics text;

- one mind map from the field of physics.

Two tasks were formulated for each information source.

First Source of Information for Tasks 1 \& 2: In the first task, the respondents were to read a text from the field of psychology-pedagogy and answer two questions. Correct answer to the first question required recall of information from the expert text, the second answer required a deeper understanding of relations between the information from the text and the corresponding terminology.

Second Source of Information for Tasks $3 \&$ 4: The second source of information was a "technical (statistics) text" with two definitions, formulae for arithmetic mean and variance and additional accompanying structured text. The third task was for the respondents to find the correct formula and suitably interpret it - it was again a task on information retrieval. The fourth task required a higher cognitive activity - it was required to deduce a new conclusion from the available facts and formula.

Third Source of Information for Tasks 5 \& 6: The third type of text and information source was a mind map. With the approval of its author, the mind map Atom from the Repetitorium of Secondary School Physics [15].

\subsection{Research Procedure}

In the first phase of the research the respondents (students) were given a questionnaire in which they were to answer the questions whether they consider themselves as 
technically or humanistically oriented individuals. It was followed by statements with which they were supposed to agree or disagree on the scale of 1-5 (where 5 meant complete agreement). The statements were divided into two groups - one group with which technically oriented individuals tend to agree, and the second group with which humanistically oriented individuals tend agree. The answers were assessed and compared whether respondents considering themselves as technically oriented would agree more often with "technical" statements, and respondents considering themselves as humanistically oriented would agree more often with "non-technical" statements. In the second phase of the research, the students were assigned texts focused on psychological-pedagogical, technical and natural science topics in an eye tracking laboratory, and six tasks they were supposed to solve one by one. During this activity, their eye movement was tracked as well as the time they fixed their gaze on a given part of the text, time needed to solve each task and other variables.

\section{$3 \quad$ Research Results}

Information obtained throughout the research were processed using statistics methods and organized into tables. Table 1 shows times needed for students to solve tasks 1-6. The table shows that students approaching the text from the predominantly holist point of view needed more time to successfully solve the tasks than students who worked using mostly the serialist approach. The only exception being the third task where serialists required more time and a higher number of fixations than holists. Even after a thorough analysis of the third task, we were not able to explain these results. The table also shows that holist students made $18 \%$ more eye fixations than serialist students.

Table 1. Solution times and number of fixations for Students with serialist and holist learning styles

\begin{tabular}{|c|c|c|c|c|c|c|c|}
\hline & Task 1 & Task 2 & Task 3 & Task 4 & Task 5 & Task 6 & Aver Val. \\
\hline Solution time of serialist students [sec] & 78 & 57 & 60 & 29 & 55 & 46 & $\mathbf{5 4}$ \\
\hline Solution time of holist students [sec] & 84 & 68 & 45 & 42 & 55 & 52 & $\mathbf{5 8}$ \\
\hline Average amount of fixations of serialists & 262 & 212 & 177 & 90 & 171 & 152 & $\mathbf{1 7 7}$ \\
\hline Average amount of fixations of holists & 319 & 239 & 155 & 157 & 202 & 184 & $\mathbf{2 0 9}$ \\
\hline
\end{tabular}

Legend:

Tasks 1 to 6 - labels for individual tasks the students solved

Aver Val - Average values for tasks 1-6 for each variable

To be able to further work with the collected data we divided students based on their predominant approach to texts (serialist or holist) into three groups (Table 2): Students using the serialist approach 0-2 times were designated "holists" (h); students using the serialist approach 4-6 times were designated "serialists" (s). Students using both methods equally were designated "undecided" (un). Picture 1 illustrates how a holist student works with a text (above) and how a serialist student does (below). 

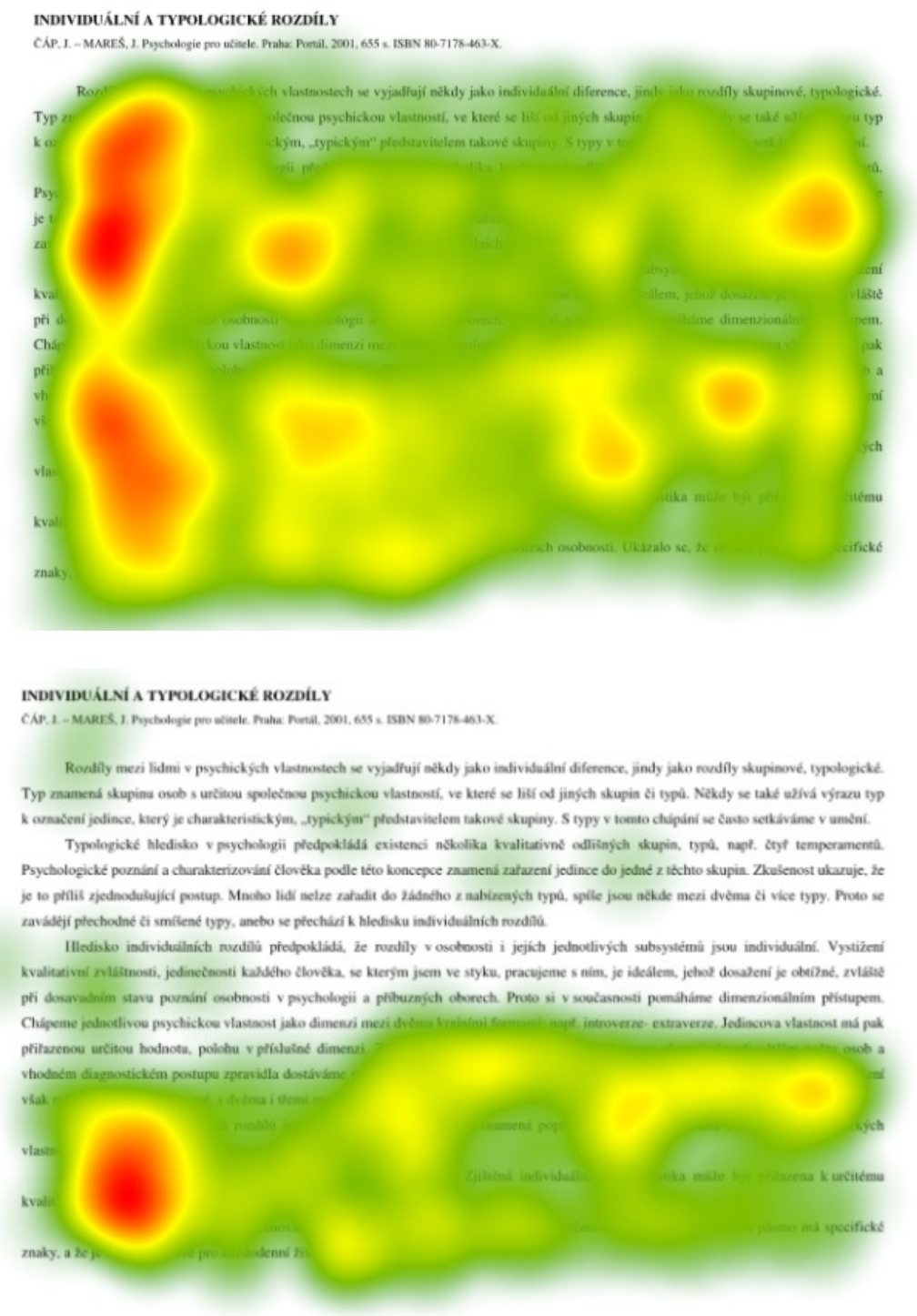

Fig. 1. Eye tracking heatmaps comparing two types of students based on their predominant style of working with a text (holist - above or serialist - below) (Task 2, Source: Authors)

Table 2 shows which approach the students took when solving the six tasks. It also includes whether each student considers themselves as technically or humanistically oriented and therefore it can be deduced how much this self-concept affects the chosen method of work with text. It shows the self-concept corresponds with the learning style of the students - out of six students considering themselves as humanistically oriented, only one used the serialist approach. 
Short Paper-Learning Styles of Students as a Factor Affecting Pedagogical Activities of a University Teacher

Table 2. Overview of students' solutions using "serialist" or "holist" approach based on their "technical" or "humanistic" self-concept

\begin{tabular}{|c|c|c|c|c|c|c|c|c|c|c|c|c|c|c|c|c|}
\hline St & $\mathbf{1}$ & $\mathbf{2}$ & $\mathbf{3}$ & $\mathbf{4}$ & $\mathbf{5}$ & $\mathbf{6}$ & $\mathbf{7}$ & $\mathbf{8}$ & $\mathbf{9}$ & $\mathbf{1 0}$ & $\mathbf{1 1}$ & $\mathbf{1 2}$ & $\mathbf{1 3}$ & $\mathbf{1 4}$ & $\mathbf{1 5}$ & $\mathbf{1 6}$ \\
\hline $\boldsymbol{N} \boldsymbol{S}$ & 1 & 3 & 4 & 3 & 4 & 0 & 3 & 3 & 4 & 4 & 5 & 3 & 2 & 1 & 3 & 5 \\
\hline $\boldsymbol{P L}$ & ho & un & s & un & s & ho & un & un & s & s & s & un & ho & ho & un & s \\
\hline $\boldsymbol{S C}$ & t & t & t & t & t & h & h & t & t & h & t & h & t & h & h & t \\
\hline
\end{tabular}

Legend:

St - student's number

NS - Number of serialist solutions

PL - Predominant learning style

SC - Technical/humanistic self-concept

$\mathbf{t}$ - students considering themselves technically oriented

$\mathbf{h}$ - students considering themselves humanistically oriented

s - serialist learning style,

ho - holist learning style,

un - undecided learning style

\section{Conclusion}

In this research, carried out with 16 respondents, an eye tracking recording of students solving 6 different tasks was analyzed. Individual styles used to solve the tasks were designated either as serialist or holist, based on their characteristics. Respondents also filled out a questionnaire which analyzed their self-concept in terms of technical or humanistic orientation.

The research showed that out of the 16 respondents, 3 are decided holists and 2 are decided serialists, therefore $31 \%$ of the respondents. For the purposes of this research, the decided holists are those respondents who solved 0-1 task using the serialist approach; the decided serialists are those respondents who solved 5-6 tasks using the serialist approach. Other respondents solved the given 6 tasks with changing approaches.

Furthermore, out of the 6 humanistically oriented students, only one used the serialist style to solve the tasks; other humanistically oriented students used the holist approach.

Additionally, out of the 10 technically oriented students, 5 used the serialist approach and 5 used the holist approach to solve the tasks. It should be noted that out of the 6 serialists 5 consider themselves as technically oriented.

When taking time required to solve the tasks into consideration and the total number of eye fixations on the text, it can be noted that the total time required to solve all the tasks was $7.4 \%$ higher for holist students and the number of eye fixations was $18 \%$ higher compared to serialist students.

Considering the limited number of respondents taking part in this research, we think it valuable to continue and expand this research. 


\section{$5 \quad$ References}

[1] G. Pask, Styles and strategies of learning. British Journal of Educational Psychology, Vol. 46, No. 2, 1976, p. 128-148. https://doi.org/10.1111/j.2044-8279.1976.tb02305.x

[2] J. Průcha and J. Veteška, Andragogický slovnik. Praha: Grada: 2014.

[3] J. Mareš, Styly učení žákủ a studentů. Praha: Portál, 1998, p. 238.

[4] J. Průcha, E. Walterová, and J. Mareš Pedagogický slovník. Praha: Portál, 2003, p. 322.

[5] M. Pisoňová, Kompetenčný profil manažéra výchovno-vzdelávacej inštitúcie. Bratislava: Iura Editioin, 2011, p. 11.

[6] M. Nakonečný, Základy psychologie. Praha: Academia, 1998, p. 590.

[7] J. Kropáč and M. Havelka, Didaktika technických předmětů. Olomouc: UP Olomouc, 2004, p. 223.

[8] E. Franus, The Dual Nature of Technical Thinking. In Technology as a challenge for school curricula.The Stockholm Llibrary of Curriculum Studies. Stockholm: Institut of Education Press, 2003, p. 141-144.

[9] P. Gavora, Žiak a text. Bratislava: Slovenské pedagogické nakladatelstvo, 1992.

[10] P. Denicola, Co je aktivní učení. Effective Learning and Teaching in Higher Education, Vol. 1. 1992. [cit. 2009-02-08]. Available at: http://search.seznam.cz/?q=POZNÁMKY+K+ POJMU+,,TECHNICKÉ+MYŠLENI'“++Jiří +Kropáč+a+Martin+Havelka+\&sourceid=sznHP1611.2015

[11] M. Miklošíková, M. Kreativita a učitelství odborných předmětů. Ostrava: ES VŠB-TUO, 2009, p. 184.

[12] M. Miklošíková, M. Didaktika pro tvưrči vysokoškolské učitele technických předmětů. Žatec: Ohře media, 2013, p. 95.

[13] V. Švec, Pedagogická prriprava budoucich učitelů: problémy a inspirace. Brno: Paido, 1999, p. 163.

[14] Z. Dobesova, Using the "Physics" of Notation to Analyse ModelBuilder Diagrams, Proceedings of SGEM 2013, 13th International Multidisciplinary Scientific GeoConference, Volume I, STEF92 Technology Ltd. Sofia, Bulgaria, p. 595-602. https://doi.org/10.5593/sgem2013/bb2.v1/s08.039

[15] R. Holubová and P. Keprtová, Repetitorium stredoškolské fyziky. Olomouc: 2012.

\section{$6 \quad$ Authors}

Martin Malcik. He received his Ph.D. in Applied mathematics and assoc. prof. in Applied informatics. He currently works at the VSB - Technical University of Ostrava. He is engaged in utilization of information technologies in aducation and human resources development. He is currently working on utilization of eyetracking for reading and understanding improvement.

Miroslava Miklosikova. She received her PhD. degree in Theory of Teaching and Learning of Vocational Subjects and assoc. prof. in Theory of Teaching and Learning of Vocational Subjects. She currently works at the VSB - Technical University of Ostrava. She is engaged in Using Psychology of education.

Article submitted 16 September 2016. Published as resubmitted by the authors 03 November 2016. 